\title{
The nutritive value of maize cultivars for broiler chickens
}

\author{
O. Lasek ${ }^{1.3}$, J. Barteczko $^{1}$, F. Borowiec ${ }^{1}$, S. Smulikowska ${ }^{2}$ \\ and R. Augustyn ${ }^{1}$
}

\author{
${ }^{1}$ University of Agriculture in Krakow, Department of Animal Nutrition and Feed Management \\ Al. Mickiewicza 24/28, 30-059 Kraków, Poland \\ ${ }^{2}$ The Kielanowski Institute of Animal Physiology and Nutrition, Polish Academy of Sciences \\ 05-110 Jabłonna, Poland
}

(Received 24 November 2011; revised version 25 May 2012; accepted 18 June 2012)

\begin{abstract}
The objective of the study was to determine the nutritive value of grain of different maize cultivars for broiler chickens. The study involved 45 Ross 308 broilers ( 9 groups with 5 chickens per group) aged 42 to 49 days. Chickens were fed the grain of maize cultivars Pioneer PR39H84, Smok, Arobase, Moncada, Pioneer PR39G12, Eurostar, Opoka, Boruta, and Nysa ad libitum. The cultivars of maize differed in basic chemical composition, contents of amino acid and fibre fractions, as well as fatty acid profiles. Variations in chemical composition among different maize cultivars had an effect on the extent of basic nutrient digestion and on the energy value of grain in broiler chickens. For practical utilization of maize in broiler feed mixtures it will be important to determine the content of insoluble fibre, as it is negatively correlated with nutrient digestibility and the $\mathrm{AME}_{\mathrm{N}}$ value of grain $(\mathrm{r}=-0.69 ; \mathrm{P}<0.05)$.
\end{abstract}

KEY WORDS: broiler chickens, maize cultivars, digestibility, amino acids, $\mathrm{AME}_{\mathrm{N}}$

\section{INTRODUCTION}

Maize (Zea mays L.) is one of the main components of broiler diets. Tables on the composition and nutritional value of feedstuffs (Sauvant et al., 2004; Smulikowska and Rutkowski, 2005) usually contain only average values for components of

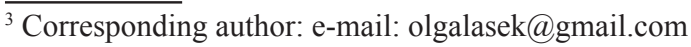


maize, thus assuming slight varietal differences. As a result of advances in plant breeding, driven by competition in the cultivar market, differences in chemical composition among cereal varieties of the same species can be greater than those between different cereal species, and this fact is not accounted for in the nutrient requirements for poultry (Lasek et al., 2011).

Song et al. (2003) reported that maize cultivars may differ not only in the content of protein but also in their starch and fibre contents, as well as in nutrient digestibility and metabolizable energy $\left(\mathrm{AME}_{\mathrm{N}}\right)$. According to Cowieson (2005) maize may contain from $71 \mathrm{~g}$ to $94 \mathrm{~g}$ of crude protein per $\mathrm{kg}$, which is less than in wheat or barley. The most important storage protein in maize is zein, which is poor in the essential amino acids, tryptophan and lysine, thus, the protein value of maize is also poor.

The $\mathrm{AME}_{\mathrm{N}}$ value of maize for poultry is higher than other cereals due to its relatively high starch $(620$ to $720 \mathrm{~g} / \mathrm{kg}$ ) and crude fat (34 to $52 \mathrm{~g} / \mathrm{kg})$ contents. It may differ, however, depending on the level of amylose in starch (Svihus et al., 2005), the amylose : amylopectin ratio, the encapsulation of starch, and the presence of different antinutrients, primarily, phytate, enzyme inhibitors, and resistant starch (Cowieson, 2005).

The aim of the study was to determine the nutritive and energy value of different maize cultivars in broiler chickens.

\section{MATERIAL AND METHODS}

\section{Maize cultivars}

The grain of nine maize cultivars varying in chemical or physical traits: flint (Pioneer PR39H84), semiflint (Smok, Arobase, Moncada, Pioneer PR39G12), semiflint/semident (Eurostar), and semident (Opoka, Boruta, Nysa) was investigated. All maize cultivars (cvs) were grown at Brzezinka (Małopolska, Poland) at the same field and growing conditions and were harvested in 2005.

\section{Animals, feeding and management}

A digestibility trial was performed on a single batch of each cultivar in 2006 by standard methods using 45 Ross 308 chickens ( 9 groups with 5 birds per group) aged 42 days. Before the digestibility trial, the chickens were kept in pens and fed a standard broiler starter diet from 0 to $14 \mathrm{~d}$ of life, then from 14 to $42 \mathrm{~d}$ of life they were kept in individual cages and fed diets based on the evaluated maize cvs and containing $\left(\mathrm{g} \mathrm{kg}^{-1}\right)$ : maize 708.5 , soyabean meal 180, fish meal 80, monocalcium phosphate 5, limestone 11, L-lysine 4.7, DL-methionine 2.8, vitamin-mineral 
premix 5, to satisfy nutrient requirements of broilers according to Smulikowska and Rutkowski (2005).

During the digestibility trial the birds were kept individually in balance cages with free access to feed and water. Chickens received only coarsely ground grain of the respective maize cultivars on an ad libitum basis. The experiment lasted $7 \mathrm{~d}$ including 4 days of adaptation, and 3 days of excreta collection. Feed intake was measured (it averaged $141.4 \mathrm{~g} / \mathrm{day}, \pm 13.8 \mathrm{~g}$ ) and excreta from each bird were quantitatively collected twice a day from trays placed under the cages, pooled and kept frozen at $-18^{\circ} \mathrm{C}$ until analysis. After the end of the experiment the chickens were killed, the abdomen was opened and the gastrointestinal tract was excised. The jejunal digesta (from the end of the duodenum to Meckel's diverticulum) was collected and $\mathrm{pH}$ and viscosity were immediately measured. All procedures were approved by the Local Animal Care and Use Committee.

\section{Chemical analyses}

The chemical composition, including amino acids, fatty acids, starch, sugars, crude and dietary fibre fractions in maize grain, was analysed. The chemical composition of maize grain and excreta was determined according to AOAC (2005), while $\alpha$-amino nitrogen in feed and excreta was determined according to method of Pahle et al. (1983) modified by Barteczko et al. (1993). The method is based on the hydrolysis of protein in feed and faeces in hydrochloric acid. After hydrolysis and distillation, ninhydrin solution was added and absorbance was determined at a wavelength of $\lambda=411 \mathrm{~nm}$ on a UNICOM UV/VIS 8675 spectrophotometer. The content of gross energy (GE) in maize grain and excreta was measured using a Parr adiabatic oxygen bomb calorimeter (KL-10, Precyzja, Bydgoszcz, Poland). The amino acid composition of maize grain and excreta was determined by liquid chromatography using an INGOS AAA-400 amino acid analyser (Prague, Czech Republic), equipped with an Ostion LG ANB (370 mm) column. Column temperature was $55^{\circ} \mathrm{C}$, reactor temperature $120^{\circ} \mathrm{C}$, detection wavelengths 440 and $570 \mathrm{~nm}$. In maize grain the contents of neutral detergent fibre (NDF), acid detergent fibre (ADF), and acid detergent lignin (ADL) were determined using an ANKOM220 Fiber Analyser (Ankom Products, NY, USA) according to AOAC (2005), whereas soluble (SDF) and insoluble (IDF) dietary fibres were analysed by an enzymatic method according to Englyst and Cummings (1988). The starch content in maize grain was determined by an enzymatic method with $\alpha$-amylase according to Faisant et al. (1995), whereas amylose and amylopectin in starch, by the method of Morrison and Laignelet (1983). Total sugars were determined by a spectrophotometric method according to Zagrodzki et al. (1969), using a colour reaction with anthron mixed with pure concentrated $\mathrm{H}_{2} \mathrm{SO}_{4}$. Before measurement the samples were deproteinized using a solution of $\mathrm{Zn}(\mathrm{CHCOO})_{2} \cdot \mathrm{H}_{2} \mathrm{O} 275.12 \mathrm{~g} / 1$ 
and $\mathrm{K}_{4} \mathrm{Fe}\left(\mathrm{CN}_{6}\right) \cdot 3 \mathrm{H}_{2} \mathrm{O} 171.99 \mathrm{~g} / \mathrm{l}$ distilled water. Absorbance was measured at a wavelength of $\lambda=620 \mathrm{~nm}$.

The composition of fatty acids was determined using a gas chromatograph (Varian Star 3400CX) with a flame-ionization detector and DB-23 column (30 m long $\times 0.5 \mathrm{~mm}$ in diameter), column temperature $100^{\circ} \mathrm{C}-205^{\circ} \mathrm{C}$, injector temperature $200^{\circ} \mathrm{C}$, detector temperature $240^{\circ} \mathrm{C}$.

In jejunal digesta, the $\mathrm{pH}$ was measured using a MERA ELWRO N $517 \mathrm{pH}$ meter (Poland), the digesta was centrifuged for $10 \mathrm{~min}$ at $10000 \mathrm{~g}$ in $4^{\circ} \mathrm{C}$ and the viscosity of the supernatant was measured with the use of a capillary tube at $37.5^{\circ} \mathrm{C}$ and calculated relative to the viscosity of water.

\section{Calculations and statistical analysis}

The apparent total tract digestibility (ATTD) of dry matter, organic matter, crude fat, $\mathrm{N}$-free extractives, and amino acids was calculated from analytical data and the quantitative measurement of feed intake and excreta output. The ATTD of protein was calculated according to Pahle et al. (1983) with the use of $\alpha$-amino nitrogen determined in feed and excreta. Apparent metabolizable energy corrected to zero nitrogen balance $\left(\mathrm{AME}_{\mathrm{N}}\right)$ was calculated according to the formula of Hill and Anderson (1958):

$$
\mathrm{AME}_{\mathrm{N}}=\mathrm{AME}-(\mathrm{BN} \mathrm{g} \times 0.0365)
$$

where: $\mathrm{BN}$ ( $\mathrm{N}$ retained), $\mathrm{g}=\mathrm{N}$ intake, $\mathrm{g}-\mathrm{N}$ excreta, $\mathrm{g}$

Means were compared for main effects using one-way analysis of variance and Tukey's test. Pearson's correlation coefficients were calculated as a measure of the strength of the association between variables (Statistica, 2005). The differences were considered significant at $\mathrm{P}<0.05$.

\section{RESULTS}

The nutrient content of maize grain varied according to cultivar (Table 1). The maximum difference in crude protein $(\mathrm{CP})$ content among the cultivars was 4.6 percentage units. The cultivars also differed considerably in the content of crude fat (CF). The Opoka and Eurostar cvs had the highest CF content, about 2.5 times that of Pioneer PR39H84. The maximum difference in starch content among cultivars was 10 percentage units. Maize grain differed in water-soluble carbohydrate content, with maximum differences of $6.2 \mathrm{~g} / \mathrm{kg}$ DM among the cultivars. Arobase $\mathrm{cv}$ had the least crude fibre of all cultivars, with the lowest NDF, ADF, and SDF contents. Maize cvs differed in gross energy content (maximum 0.27 MJ). 


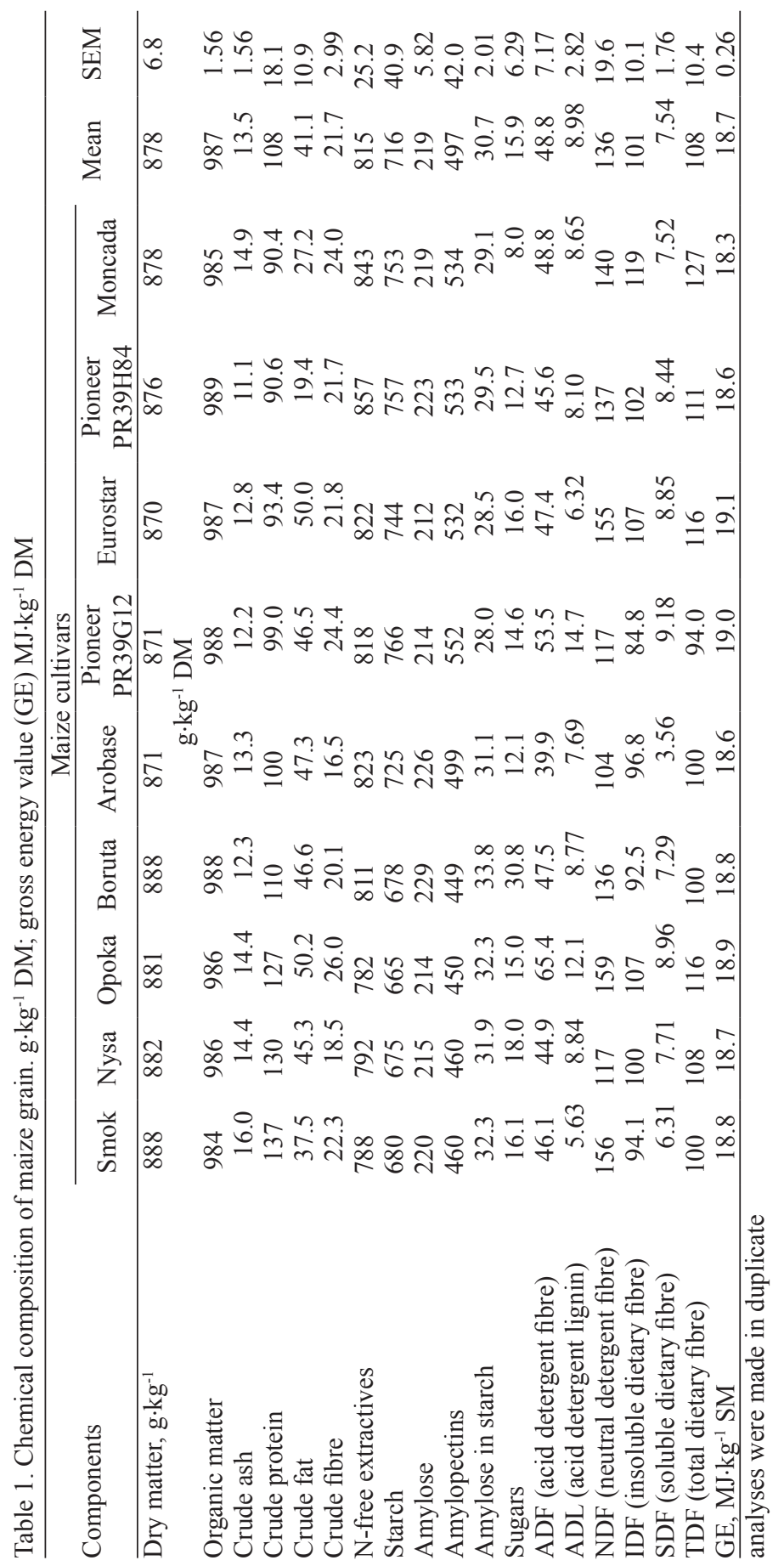


Maize cvs also differed in amino acid content (Table 2). Crude fat was composed mostly of unsaturated fatty acids (Table 3 ). The largest differences among cultivars were found for oleic (10\%) and linoleic acids (13.9\%). Arobase and Moncada cvs had the highest content of polyunsaturated fatty acids (PUFA). All maize cultivars were characterized by a high, but varied n-6/n-3 PUFA ratio ranging from 25 to 44 (Table 3).

The ATTD of the main nutrients in chickens varied significantly $(\mathrm{P}<0.05)$ among cultivars (Table 4). The highest coefficients of CP digestibility were determined in Boruta and Arobase maize, and the lowest, in cv Moncada (8.9 percentage units; $\mathrm{P}<0.05$ ). The ATTD of crude fat averaged $67.4 \%$, with withincultivar deviations of $\pm 15.4(\mathrm{P}<0.05)$; the lowest values were found for Pioneer PR39H84 and Moncada cvs. The ATTD of starch averaged 99\%, the lowest values were found for Arobase $\mathrm{cv}(\mathrm{P}<0.05)$. The $\mathrm{pH}$ values of jejunal digesta averaged 5.8, the difference between Arobase cv and Pioneer PR39H84 cv was statistically significant (Table 4). The jejunal digesta viscosity averaged 1.82 and did not differ between cultivars.

The maize cvs differed $(\mathrm{P}<0.05)$ in $\mathrm{AME}_{\mathrm{N}}$ value $($ Table 4$)$. The lowest $\mathrm{AME}_{\mathrm{N}}$ value was found in Pioneer PR39H84 cv and was $1.44 \mathrm{MJ}$ lower compared with that determined for Pioneer PR39G12 cv.

The amino acids of Boruta, Nysa, Smok and Arobase cvs were digested better compared with the low-protein cvs Eurostar, Pioneer PR39G12, Pioneer PR39H84, and Moncada (Table 5). Among essential amino acids, the ATTD averaged from $72 \%$ for lysine to $91.4 \%$ for leucine, with lysine digestibility being more variable than the other essential amino acids (Table 5).

The IDF in maize was negatively correlated with sugar content as well as with organic matter and crude fat digestibility and with $\mathrm{AME}_{\mathrm{N}}$ value $(\mathrm{P}<0.05)$, while the SDF was positively correlated with the $\mathrm{pH}$ of jejunal digesta (data not shown), starch digestibility, and $\mathrm{AME}_{\mathrm{N}}$ value (Table 6). There was a positive correlation of digesta $\mathrm{pH}$ with its viscosity $(\mathrm{r}=0.61 ; \mathrm{P}<0.05)$ and negative correlation with crude fat digestibility $(\mathrm{r}=0.45 ; \mathrm{P}<0.05)$. The ATTD of organic matter and crude fat was positively correlated with the content of sugars in grain. Neither $\mathrm{pH}$ nor viscosity of jejunal digesta affected digestibility of nutrients. $\mathrm{AME}_{\mathrm{N}}$ value was negatively correlated with IDF and positively with SDF and sugar content in maize grain, as well as positively correlated with the digestibility of organic matter, crude protein, crude fat, and starch (Table 6). 


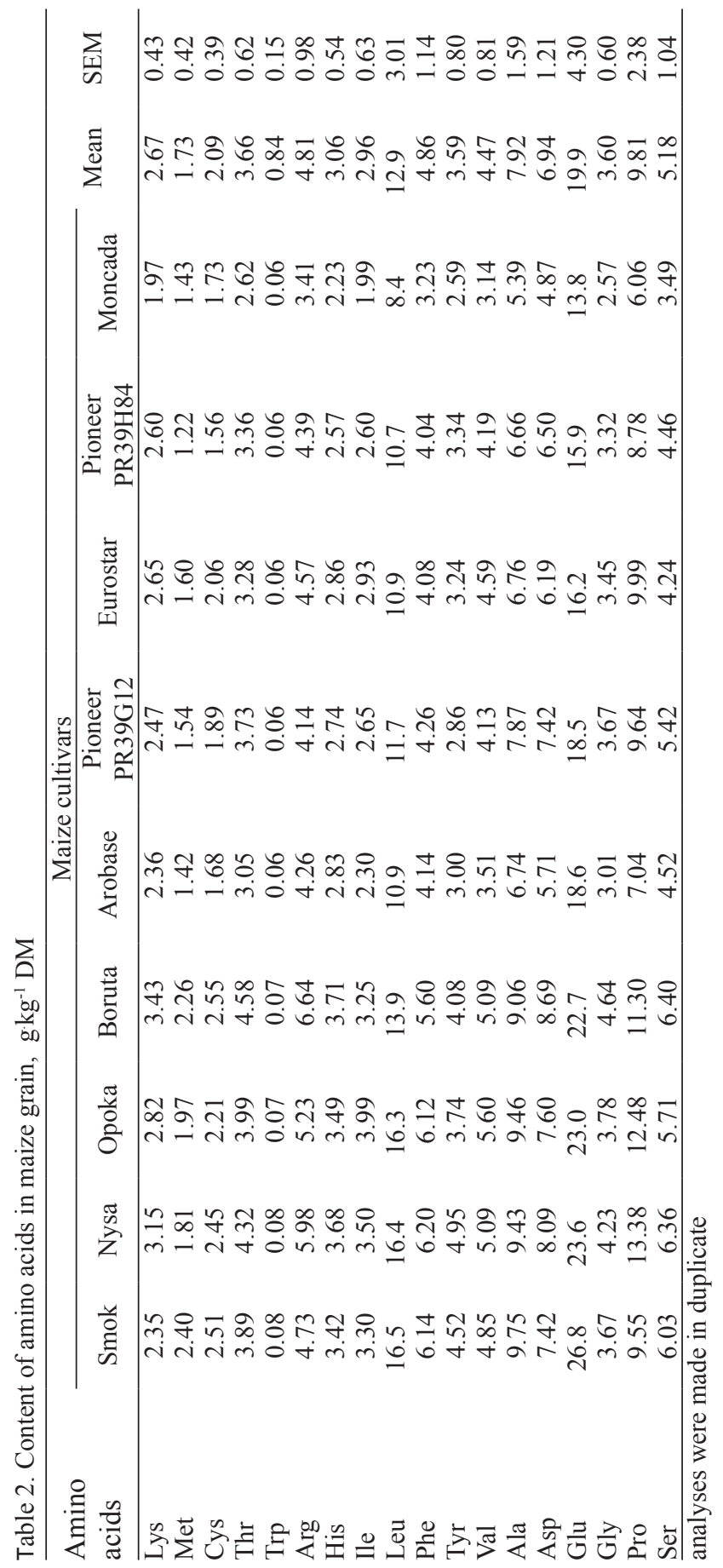




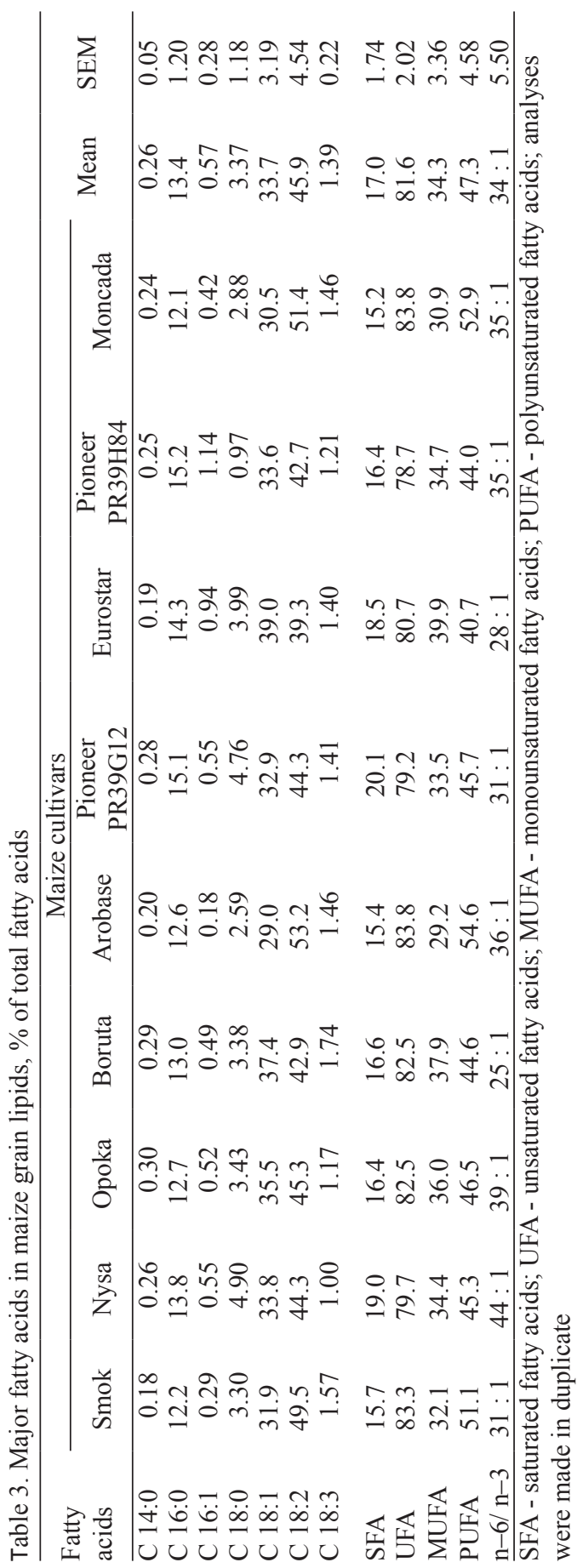




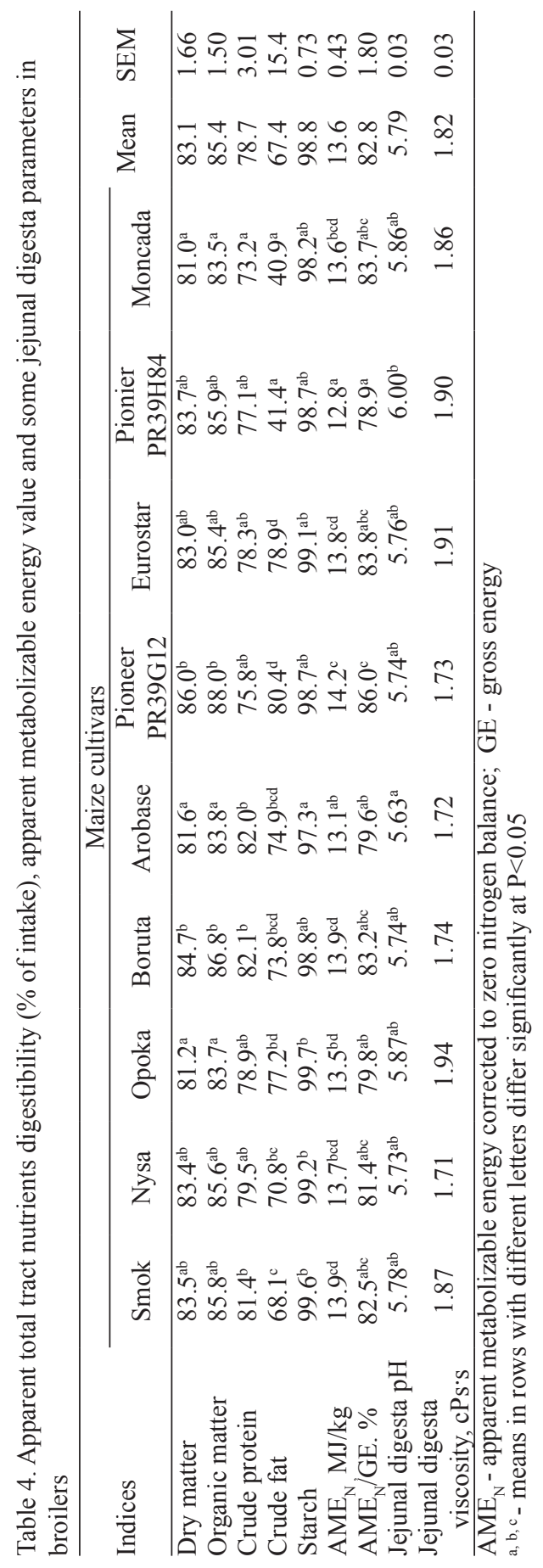




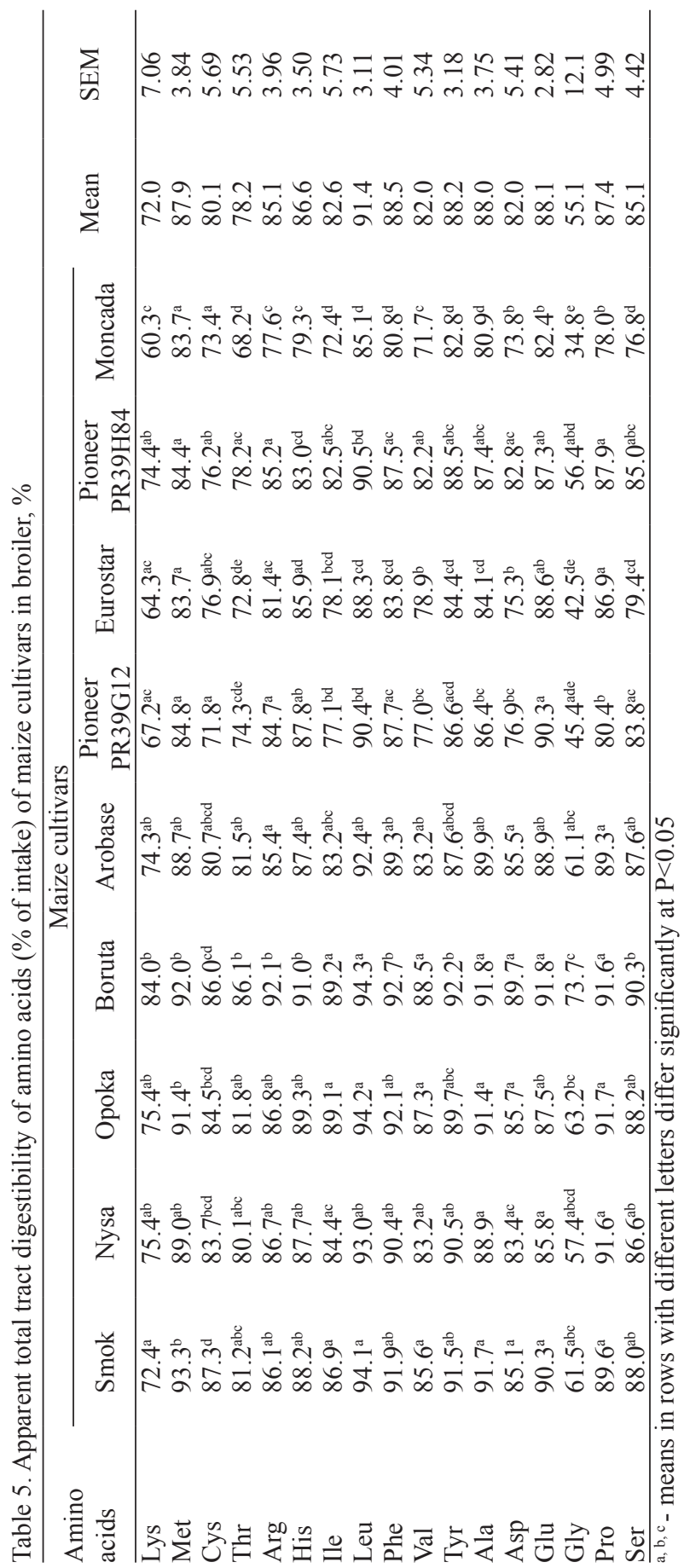


LASEK O. ET AL.

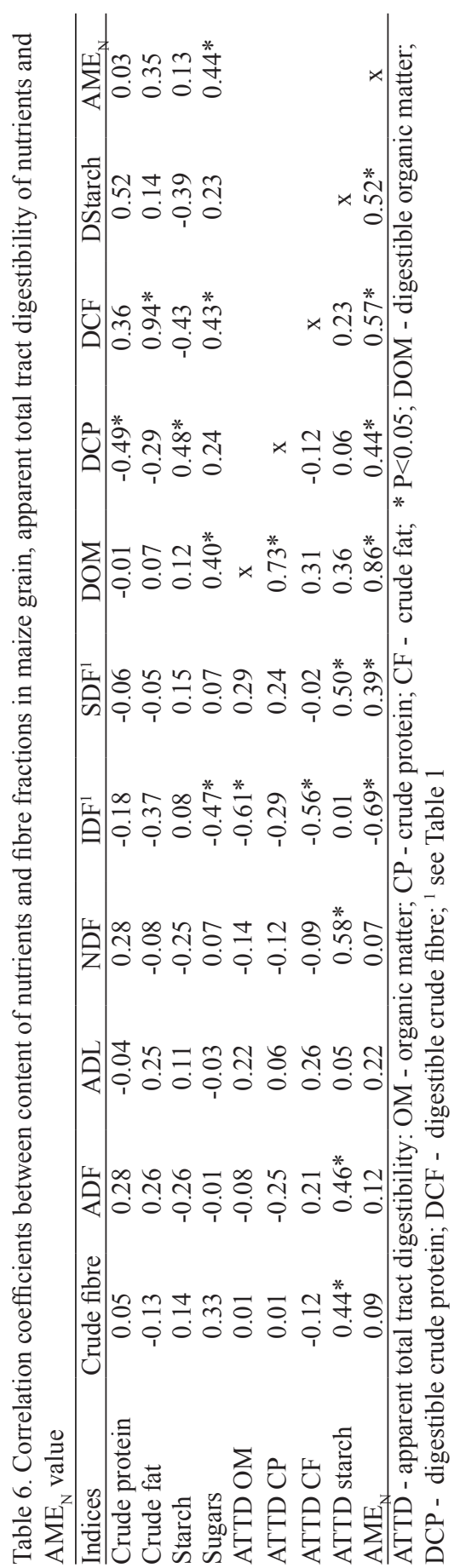




\section{DISCUSSION}

Maize grain is relatively low in crude protein, but high in crude fat and metabolizable energy value for broiler chickens $\left(\mathrm{AME}_{\mathrm{N}}\right)$ in comparison with other cereals (European Table, 1989; Sauvant et al., 2004). In the grain of the nine maize cvs used in our experiment, the average crude protein content was higher than that reported by Moore et al. (2008) and similar to the average values reported by Korniewicz et al. (2000). The nutritive value of maize protein varies according to cultivar, type of grain (dent, flint, dent/flint), growing conditions (Korniewicz et al., 2000), grain drying temperature (Kaczmarek et al., 2007), starch structure (Svihus et al., 2005), and presence of antinutrients, primarily, phytate, enzyme inhibitors, and resistant starch (Cowieson, 2005).

Crude fat content affects the content of gross energy (GE) and the metabolizable energy $\left(\mathrm{AME}_{\mathrm{N}}\right)$ value in maize grain. The average proportion of fat in maize cultivars evaluated in our study was lower than reported by Korniewicz et al. (2000), whereas similar as in maize grains tested by Applegate (2005) and Moore et al. (2008). Two of the cultivars evaluated in our study, Pioneer PR39H84 and Moncada, had a crude fat content much lower, however, than other cultivars. Also Song et al. (2003) reported considerable differences in crude fat content among maize cultivars. In our study, the content of oleic, linoleic and linolenic acids in maize grain fat was slightly different from that given in Sauvant et al. (2004) and European Tables (1989) - the content of linoleic acid was lower and linolenic acid higher, so the n-6/n-3 FA proportion averaged 34 (Table 3 ). It is well known that the fatty acid composition of a diet affects the fatty acid profile in broiler meat, so fat used as a supplement of feed mixtures based on maize should contain a considerable proportion of n-3 FA.

Starch constitutes approximately $700 \mathrm{~g} / \mathrm{kg}$ DM of maize grain (Bach Knudsen, 1997; Korniewicz et al., 2000). In the present study the cultivars with the highest starch content (about $75 \%$ DM) also had the lowest CP content. Interestingly, there was a significant negative correlation between starch and sugar content $(\mathrm{r}=0.59$; $\mathrm{P}<0.05$ ). Both the starch content and the proportion of amylose to amylopectins in starch are variable in maize. In the maize cultivars used in our study, the proportion of amylose in starch was $30.5 \%$, which corresponds to the values reported for normal amylose maize (Tester et al., 2004).

Compared with other cereal species, maize grain contains less crude fibre, non-starch polysaccharides (NSP), and non-cellulose polysaccharides (NCP) (Cowieson, 2005). Bach Knudsen (1997) reported that total dietary fibre (TDF) consists of about $108 \mathrm{~g} / \mathrm{kg}$ of DM, similarly as in our study. The arabinoxylans and $\beta$-glucans found in dietary fibre of some cereals absorb water to form hydrogels, which increase the viscosity of small intestinal digesta. This can reduce the activity 
of digestive enzymes and the absorption of nutrients. Compared with other cereal species, maize grain contains a low proportion of the insoluble fraction in total non-starch polysaccharides and considerably lower amounts of $\beta$-glucan, and these substances have no adverse effect on the extent of the digestion of maize nutrients in birds (Cowieson, 2005).

In the analysed maize grain, the average crude fibre content was lower than that given by Sauvant et al. (2004), while the content of acid- and neutral- detergent fibre varied among cultivars, similarly as in the study by Moore et al. (2008).

It is assumed that maize nutrients are generally characterized by high digestibility in broilers (European Table, 1989; Zanella et al., 1999). The results of our study indicate that some cultivars of maize can differ in the extent of nutrient digestion and in energy value. In our study, DM and OM digestibilities were similar, but crude fat digestibility was lower compared with the results obtained by Kaczmarek et al. (2007) and given in the European Table (1989). In our study, the lower coefficients of apparent crude fat digestibility were obtained for cultivars with a very low crude fat content (Pioneer PR39H84 and Moncada). Due to this, the correlation between crude fat content and coefficient of fat digestibility was - $0.94(\mathrm{P}<0.01)$. Lipids are present in maize grain in the outer skin, a great part as indigestible waxes, and in germ and endosperm, mainly as triglycerides and phospholipids (Cowieson, 2005). It can be assumed that in grain of both lowfat cultivars used in the present study, the distribution of crude fat between the outer skin, germ and endosperm favoured the outer skin, which makes crude fat less digestible by birds. A similar low digestibility of fat in broilers fed diets containing more than 50\% maize grain was reported by Batal and Parsons (2002), who showed a significant effect of broiler age on the digestibility of fat.

In our study, the apparent coefficients of amino acid digestibility were positively correlated with crude protein content in maize grain ( $\mathrm{r}$ from 0.40 for lysine to 0.75 for methionine) but there were, on average, about $4 \%$ lower than reported by Song et al. (2003). The coefficients of essential amino acid digestibility were negatively correlated with the TDF and IDF content in grain.

Generally, maize grain has a lower content of non-starch polysaccharides (NSP) than the other cereal grains, and the physicochemical characteristics of NSP are different. The results of our study confirm that the ratio of SDF in total dietary fibre is low and that maize SDF has no viscous or anitinutritional properties, as the jejunal digesta viscosity in chickens fed with maize ranged between 1.71 to 1.90 and was affected by neither amino acid digestibility nor $\mathrm{AME}_{\mathrm{N}}$ values. Nonetheless, the significant negative correlation between IDF, amino acid digestibility, and $\mathrm{AME}_{\mathrm{N}}$ values suggest the antinutritional potency of the maize IDF fraction, possibly by a cage effect. Due to supplementation of the maize-based diets with different enzymes (xylanase, $\alpha$-galactosidase, $\beta$-mannanase, pectinase, 
$\alpha$-amylase), an improvement of broiler performance was reported (Gracia et al. 2003; Cowieson, 2005). It can be attributed to release of the cage effect as well as to increased degradation of the cell walls and greater utilization of hexoses and pentoses from the small intestine.

The energy value of maize grain for broilers due to a higher content of crude fat and starch is greater compared with other cereals. In the present experiment, the $\mathrm{AME}_{\mathrm{N}}$ value of maize cultivars was similar to that determined in maize grain by Applegate (2005). The energy value of the analysed maize cultivars was positively correlated with sugar content $(\mathrm{r}=0.51 ; \mathrm{P}<0.05)$ and negatively with the TDF and IDF contents in grain $(\mathrm{r}=-0.60$ and -0.69 , respectively; $\mathrm{P}<0.05)$.

In the present experiment, maize cultivar had no effect on the viscosity of jejunal digesta, but was found to have a significant effect on digesta $\mathrm{pH}$. A slightly lower viscosity compared with our study was reported by Maisonnier et al. (2001) for small intestinal digesta of broilers fed maize. In other studies, a slightly higher viscosity of jejunal digesta of 21-day-old broilers receiving a diet with about $60 \%$ maize grain was reported (Gonzàlez-Alvarado et al., 2007). A similar $\mathrm{pH}$ level to that in our study was determined in 22-day-old broiler chickens receiving a diet with about $50 \%$ maize grain by Gracia et al. (2003), while almost twice lower values were obtained by Gonzàlez-Alvarado et al. (2007). The results of our study showed that differences in the composition of maize cultivars had no influence on the development of the gastrointestinal tract.

\section{CONCLUSIONS}

In summary, the basic chemical composition, the contents of gross energy, amino acids, and fibre, as well as the fatty acid profile of maize grain can differ among maize cultivars, but it has not been proved that batch-to-batch contents within a cultivar are similar. Variation in the chemical composition of maize grain had an effect on the extent of basic nutrient digestion and energy value of grain in broiler chickens. Apart from the determination of protein content for practical utilization of maize it is important to determine the insoluble fibre fraction, as it is negatively correlated with nutrient digestibility and the $\mathrm{AME}_{\mathrm{N}}$ value of maize.

\section{REFERENCES}

AOAC, 2005. Association of Official Analytical Chemists, Official Methods of Analysis. $18^{\text {th }}$ Edition. Washington, DC

Applegate T.J., 2005. The nutritional value of dehulled-degermed corn for broiler chickens and its impact on nutrient excretion. Poultry Sci. 84, 742-747 
Bach Knudsen K.E., 1997. Carbohydrate and lignin contents of plant materials used in animal feeding. Anim. Feed Sci. Tech. 67, 319-338

Barteczko J., Kamiński J., Marszałek A., 1993. Effect of methods of determination of faecal and urinary nitrogen on the value of apparent protein digestibility coefficient in laying hens of low or high productivity (in Polish). Zesz. nauk. PTZ 8, 188-194

Batal A.B., Parson C.M., 2002. Effect of age on nutrient digestibility in chicks fed different diets. Poultry Sci. 81, 400-407

Cowieson A.J., 2005. Factors that affect the nutritional value of maize for broilers. Anim. Feed Sci. Tech. 119, 293-305

Englyst H. N., Cumming J.H., 1988. Improved method for measurement of dietary fibre as nonstarch polysaccharides in plant food. J. Assn. Off. Anal. Chem. 71, 808-814

European Table of Energy Values for Poultry Feedstuffs, 1989. $2^{\text {nd }}$ Edition. Subcommittee Energy of the Working Group nr 2 Nutrition of the European Federation of Branches of the Worlds Poultry Science Association. Beekbergen (the Netherlands)

Faisant N., Planchot V., Kozlowski F., Pacouret M.P., Colonna P., Champ M., 1995. Resistant starch determination adapted to products containing high level of resistant starch. Sci. Alim. 15, 83-89

Gonzàlez-Alvarado J.M., Jiménez-Moreno E., Làzaro R., Mateos G.G., 2007. Effect of type of cereal, heat processing of the cereal, and inclusion of fiber in the diet on productive performance and digestive traits of broilers. Poultry Sci. 86, 1705-1715

Gracia M.I., Aranibar M.J., Lázaro R., Medel P., Mateos G.G., 2003. Alpha-amylase supplementation of broiler diets based on corn. Poultry Sci. 82, 436-442

Hill F.W., Anderson D.L., 1958. Comparison of metabolizable energy and productive energy determinations with growing chicks. J. Nutr. 64, 587-603

INGOS, 2001. Amino Acid Analyser AAA400. Manual for ChromuLan. INGOS spol. s r.o. Prague (Czech Republic)

Kaczmarek S., Józefiak D., Bochenek M., Rutkowski A., 2007. The effect of drying temperature of maize grain on nutrient digestibility and nitrogen retention by growing broiler chickens. In: Proceedings of XIX International Poultry Symposium PB WPSA, Olsztyn (Poland), p. 93

Korniewicz A., Kosmala I., Czarnik-Matusewicz H., Paleczek B., 2000. Nutrient contents of varied maize crossbreed (in Polish) Ann. Anim. Sci. 27, 289-303

Lasek O., Barteczko J., Augustyn R., Smulikowska S., Borowiec F., 2011. Nutritional and energy value of wheat cultivars for broiler chickens. J. Anim. Feed Sci. 20, 246-258

Maisonnier S., Gomez J., Carré B., 2001. Nutrient digestibilities and intestinal viscosities in broiler chickens fed on wheat diets, as compared to guar-gum added maize diets. Brit. Poultry Sci. 42, $102-110$

Moore S.M., Stalder K.J., Beitz D.C., Stahl C.H., Fithian W.A., Bregendahl K., 2008. The correlation of chemical and physical corn kernel traits with production performance in broiler chickens and laying hens. Poultry Sci. 87, 665-676

Morrison W.R., Laignelet B., 1983. An improved colorimetric procedure for determining apparent and total amylose in cereal and other starches. J. Cereal Sci. 1, 9-20

Pahle T., Köhler R., Halle I., Jeroch H., Gebhardt G., 1983. Metodische Untersuchungen zur Bestimmung der Verdaulichkeit des Rohproteins beim Hühnergeflügel. Arch. Tierernähr. 4/5, 367-370

Sauvant D., Perez J.M., Tran G. (Editors), 2004. Tables of Composition and Nutritional Value of Feed Materials. Pigs, Poultry, Cattle, Sheep, Goats, Rabbits, Horses and Fish. $2^{\text {nd }}$ revised Edition. INRA, Wageningen Academic Publishers

Smulikowska S., Rutkowski A. (Editors), 2005. Recommended Allowances and Nutritive Value of Feedstuffs. Poultry Feeding Standards (in Polish). $4^{\text {th }}$ Edition. The Kielanowski Institute of Animal Physiology and Nutrition, PAS, Jabłonna (Poland) and Polish Branch of WPSA 
Song G.L., Li D.F., Piao X.S., Chi F., Wang J.T., 2003. Comparisons of amino acid availability by different methods and metabolizable energy determination of a Chinese variety of high oil corn. Poultry Sci. 82, 1017-1023

Statistica, 2005. StatSoft, Inc (data analysis software system), Version 7.1 www.statsoft.com

Svihus B., Uhlen A.K., Harstad O.M., 2005. Effect of starch granule structure, associated components and processing on nutritive value of cereal starch: A review. Anim. Feed Sci. Tech. 122, 303-320

Tester R.F., Karkalas I., Qi X., 2004. Starch structure and digestibility. Enzyme - substrate relationship. World Poultry Sci. J. 60, 186-195

Zagrodzki S., Niedzielski Z., Maro M., 1969. Spectrometric determination of sugars (in Polish). Przem. Spoż., 1, 4

Zanella I., Sakomura N.K., Silversides F.G., Fiqueirdo A., Pack M., 1999. Effect of enzyme supplementation of broiler diets based on maize and soybeans. Poultry Sci. 78, 561-568 